\title{
ANALISIS ALTMAN UNTUK MEMPREDIKSI KEBERLANGSUNGAN USAHA LEMBAGA KEUANGAN MIKRO SYARIAH DI KABUPATEN TANAH DATAR
}

\author{
Elfina Yenti \\ Fakultas Ekonomi dan Bisnis Islam IAIN Batusangkar \\ Jl. Jenderal Sudirman No. 137, Lima Kaum Batusangkar \\ e-mail: elfina.yenti02@gmail.com
}

\begin{abstract}
This research was conducted to predict the business continuity (going concern) microfinance institutions sharia in tahah datar using the Altman Z-Score. The purpose of this research was to analyze the performance and predict the sustainability of microfinance institutions sharia in tanah datar. Because of the presence of islamic micro finance institutions in tanah datar help people who need additional capital, because people have limited access to other financial institutions, especially banks. The result of this research are expected to be considered by the management to increase or improve the state of the company in the future. For the goverment is expected to have implications for the measures taken, as the goverment took responcibility for the empowermenr of micro, small and medium enterprices as referred to in the Act No. 20 of 2008.
\end{abstract}

Kata kunci: prediksi kelangsungan usaha, metode Altman, LKMS

\section{PENDAHULUAN}

$\mathcal{K}$ eberadaan Usaha Mikro, Kecil dan Kenengah di Indonesia semakin jelas dan semakin diperhitungkan dalam perekonomian Indonesia. Ini terlihat dari upaya yang dilakukan pemerintah untuk terus meningkatkan peran dan kontribusi Usaha Mikro, Kecil dan Menengah dalam perekonomian nasional. Upaya yang dilakukan antara lain; menetapkan bahwa pemerataan hasil pembangunan harus mencakup program memberikan kesempatan kepada Usaha Mikro, Kecil dan Menengah untuk memperluas dan mengatur usahanya, memperkuat permodalan, meningkatkan keterampilan, dan membantu pemasaran. Upaya ini semakin nyata dengan disahkannya UU No. 20 tahun 2008 tentang Usaha Mikro, Kecil dan Menengah.
Adanya UU tersebut memberi energi baru bagi kegiatan Usaha Mikro, Kecil dan Menengah yang secara langsung mendorong pertumbuhan ekonomi untuk masyarakat menengah ke bawah yang juga mampu memberikan kontribusi bagi Indonesia dari segi makro ekonomi. Pendapatan Domestik Bruto Indonesia yang dihasilkan dari kegiatan Usaha Mikro, Kecil dan Menengah mencapai $57,12 \%$. Berdasarkan data Kementerian Koperasi dan Usaha Kecil Menengah tahun 2013, jumlah unit Usaha Mikro, Kecil dan Menengah (UMKM) mencapai 55,2 juta unit atau 99,98\% terhadap total unit usaha di Indonesia. Selain itu, jumlah tenaga kerja yang terlibat di dalamnya mencapai 101,72 juta orang atau sekitar $97,3 \%$ dari total seluruh tenaga kerja di 
Indonesia. (Departemen Koperasi: Data dan Informasi : 2013)

Pesatnya perkembangan Usaha Mikro, Kecil dan Menengah di Indonesia mengharuskan pengusaha untuk lebih profesional dalam menjalankan bisnisnya. Tidak jarang dari pelaku Usaha Mikro, Kecil dan Menengah (UMKM) harus menutup usaha yang telah dirintis dan dikembangkan karena ketidakmantapan landasan dalam melakukan kegiatan operasional bahkan mengalami kerugian dan terpaksa ditutup. Pengelolaan yang profesional mutlak harus dilakukan oleh para pengusaha agar dapat bertahan dan berkembang di tengah persaingan yang semakin ketat. Karena salah satu tujuan yang paling mendasar dan yang ingin dicapai oleh setiap perusahaan adalah berusaha untuk mempertahankan kelangsungan usaha pada masa yang akan datang.

Kelangsungan usaha (going concern) merupakan salah satu asumsi yang mendasari penyajian dan pelaporan keuangan. Apabila laporan keuangan disusun atas suatu dasar kelangsungan usaha (going concern), maka dianggap bahwa entitas akan mampu melanjutkan kegiatannya pada masa mendatang. Tentunya melalui kinerja yang diharapkan lebih baik dan terhindar dari financial distress.

Lembaga Keuangan Mikro Syariah merupakan bagian dari UMKM yang keberadaannya menjadi solusi bagi masyarakat kategori pengusaha mikro untuk mendapatkan tambahan modal dalam pengembangan usaha mereka. Di antara Lembaga Keuangan Mikro (LKM) Syariah yang ada di Kabupaten Tanah Datar adalah KJKS BMT Simabur, KJKS BMT Al Hikmah Tabek Patah, KJKS BMT Ampek Jurai Lantai Batu, KJKS BMT El-Amin Batusangkar, KJKS BMT Al Makmur Supanjang, KJKS BMT Masjid Raya Salimpaung, KPN Syariah Al Ikhlas
STAIN Batusangkar dan BMT Mahmud Yunus STAIN Batusangkar.

Sehubungan dengan jumlah LKM Syariah di atas, Menurut Yusman, Direktur Pengaturan Penelitian dan Pengembangan Industri Keuangan Non Bank, berdasarkan pemetaan Otoritas Jasa Keuangan (OJK) diperkirakan tidak sampai 10\% LKM yang akan bertahan. Jumlah LKM itu bisa menyusut karena tidak memenuhi aturan perizinan usaha dan kelembagaan yang ditetapkan OJK, yang mulai diberlakukan Januari 2015. Selain itu, OJK juga mengatur besaran modal yang harus disetor oleh LKM. Untuk tingkat kecamatan OJK mewajibkan jumlah minimal modal disetor Rp. 100 juta. OJK juga berencana menggandeng pemerintah daerah (pemda) untuk mengawasi kinerja LKM tersebut. (Murdaningsih: 2014).

Jika KJKS BMT termasuk kepada LKM yang akan menyusut, secara mikro dapat dikatakan mengalami kebangkrutan. $\mathrm{Hal}$ ini juga akan mempengaruhi keberlangsungan operasional Usaha Mikro secara khusus dan roda perekonomian secara umum yang ada di sekitarnya. Secara makro akan berimplikasi terhadap perkembangan ekonomi Islam itu sendiri, karena akan mempengaruhi opini masyarakat secara umum bahwa lembaga keuangan Islam itu tidak bisa eksis di tengah-tengah perkembangan lembaga keuangan lainnya.

Beberapa temuan kasus yang terkait dengan kondisi keuangan LKM Syariah di Tanah Datar diantaranya Kondisi Aset, Pembiayaan, Modal, Pendapatan, Beban dan Laba (Rugi). Berdasarkan data keuangan KJKS BMT El Amin (dalam ribuan rupiah) jumlah aset sebesar $\mathrm{Rp}$ 231.428,4,-, dan modal sebesar Rp 70.751,-Komposisi modal terhadap aset sebesar $30 \%$. Artinya $70 \%$ aset dibiayai dengan 
hutang. Sementara dari kemampuan menghasilkan laba KJKS BMT El Amin pada tahun 2014 mengalami kerugian sebesar Rp 3.020,2,-, dan pada tutup buku tahun 2013 tidak melaksanakan Rapat Anggota Tahunan (Elna : Wawancara : 2015).

Sedangkan pada KJKS BMT AlHikmah (dalam ribuan rupiah) aset yang dimiliki sebesar $\operatorname{Rp} 810.671,6,-$ dan modal sebesar Rp 43.274,9,-. Komposisi modal terhadap aset sebesar 5,3\%. Artinya 94,7\% aset didanai dari hutang. Sementara dari kemampuan menghasilkan laba KJKS BMT Al-Hikmah pada tahun 2014 sebesar Rp 7.231,6., dari jumlah pembiayaan yang disalurkan sebesar Rp 595.034,4,-- Karena sebagian besar pendapatan yang diperoleh akan dibayarkan sebagai biaya modal atas besarnya hutang yang ada.

Berdasarkan kondisi di atas perlu adanya antisipasi sebelum terjadi kebangkrutan sehingga keberlangsungan usaha KJKS BMT yang ada di Tanah Datar tetap terjaga. Untuk itu perlu dilakukan analisis agar memperoleh peringatan awal kebangkrutan. Karena semakin awal tanda-tanda kebangkrutan tersebut diketahui, semakin baik bagi pihak manajemen untuk bisa melakukan perbaikan. Hasil analisis ini diharapkan dapat menjadi bahan kajian dan bahan pertimbangan bagi pihak-pihak terkait dalam rangka menjaga keberlangsungan LKM Syariah. Pemerintah daerah juga berkewajiban untuk memajukan perekonomian masyarakatnya, sehingga dia merasa punya kepentingan untuk tetap eksisnya Lembaga Keuangan Mikro Syariah tersebut. Apalagi Pemda merupakan partner dari OJK yang bertanggung jawab dalam pembinaan dan pengawasan terhadap LKM.

\section{METODE PENELITIAN}

Jenis penelitian ini adalah field research atau penelitian lapangan dengan maksud untuk meneliti secara objektif apa yang terjadi di lokasi penelitian. Penelitian ini bersifat deskriptif analisis yaitu memberi gambaran dan menerangkan keadaan Lembaga Keuangan Mikro Syariah yang ada di Tanah Datar. Data penelitian berasal dari data sekunder berupa laporan keuangan yang akan dianalisis dengan teknik kuantitatif. Teknik analisis menggunakan rasio-rasio yang berkaitan dengan kesehatan perusahaan serta menggunakan Metode Z-score.

Z-score adalah nilai yang ditentukan dari hitungan standar kali rasio-rasio keuangan yang menunjukkan tingkat kemungkinan kebangkrutan perusahaan, sehingga dapat diprediksi apakah kelangsungan perusahaan dapat terwujud.

Dimana:

Z-score $=6.56 \frac{W C}{T A}+3.26 \frac{\mathrm{RE}}{T A}+$

$6.72 \frac{\text { EBIT }}{T A}+1.05 \frac{M V E}{B V D}$

WC/TA : Working Capital/Total Asset

RE/TA : Retained Earning/Total Asset

EBIT/TA : Earning Before Income Tax/Total asset

EBIT/TA : Market ValueEquity/Book Value of Debt

\section{Pedoman Perhitungan Nilai Z-Score:}

Z-Score $\leq 1.10$, artinya kondisi kesehatan keuangan suatu perusahaan tidak baik dan diprediksi akan segera mengalami kebangkrutan.

$1.10>$ Z-Score $<2.60$, artinya suatu perusahaan berada dalam gray area di mana suatu perusahaan berada dalam ambang kebangkrutan.

Z-Score $\geq 2.60$, artinya kondisi kesehatan keuangan suatu perusahaan berada dalam 
keadaan baik di mana perusahaan tersebut tidak diprediksi mengalami kebangkrutan.

\section{PEMBAHASAN}

\section{Tinjauan Pustaka}

\section{Laporan Keuangan}

Setiap perusahaan memerlukan sistem pencatatan dalam pembukuan (akuntansi) untuk mengetahui aktivitas usaha dan hasil usaha yang telah dicapai. Laporan keuangan merupakan output dan hasil akhir dari proses akuntansi. Laporan keuangan inilah yang menjadi bahan informasi bagi para pemakainya sebagai salah satu bahan dalam proses pengambilan keputusan. Di samping sebagai informasi, laporan keuangan juga sebagai pertanggungjawaban atau accountability. Sekaligus menggambarkan indikator kesuksesan suatu perusahaan dalam mencapai tujuannya (Harahap, 2011: 205).

Laporan keuangan merupakan objek dari analisis terhadap laporan keuangan. Gambaran suatu bank pada umumnya biasanya tercermin dalam laporan keuangannya. Laporan keuangan bertujuan untuk menyediakan informasi yang bermanfaat bagi pihak-pihak yang berkepentingan (pengguna laporan keuangan) dalam pengambilan keputusan ekonomi yang rasional (Muhammad, 2005 : 151).

Laporan keuangan yang diterbitkan oleh perusahaan merupakan salah satu sumber informasi mengenai posisi keuangan perusahaan, kinerja serta perubahan posisi keuangan perusahaan, yang sangat berguna untuk mendukung pengambilan keputusan yang tepat. Dalam Suherli (2006:) Laporan keuangan beserta pengungkapannya dibuat perusahaan dengan tujuan memberikan informasi yang berguna untuk pengambilan keputusan investasi dan pendanaan, seperti yang dinyatakan dalam SFAC No. 1 bahwa laporan keuangan harus memberikan informasi:

1. Untuk keputusan investasi dan kredit

2. Mengenai jumlah dan timing arus kas

3. Mengenai aktiva dan kewajiban

4. Mengenai kinerja perusahaan

5. Mengenai sumber dan penggunaan kas

6. Penjelas dan interpretif

7. Untuk menilai bentuk pertanggungjawaban manajemen (stewardship).

Terlepas dari konsep di atas, sebenarnya Islam telah menggariskan adanya suatu pertanggungjawaban dalam setiap pekerjaan yang dilakukan, sebagaimana firman Allah dalam surat An-Nahl ayat 93, yang berbunyi:

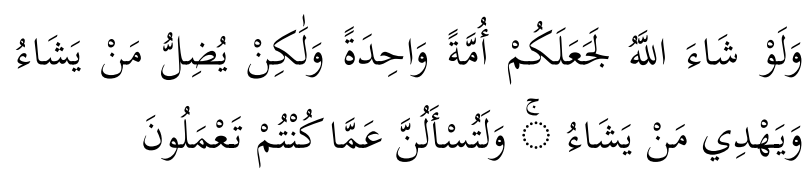

Dan kalau Allah menghendaki, niscaya Dia menjadikan kamu satu umat (saja), tetapi Allah menyesatkan siapa yang dikehendakiNya dan memberi petunjuk kepada siapa yang dikehendaki-Nya. dan Sesungguhnya kamu akan ditanya tentang apa yang telah kamu kerjakan. (Q.S. an-Nahl [16]: 93)

Laporan keuangan merupakan objek dari analisis laporan keuangan, oleh karena itu perlu memahami latar belakang penyusunan dan penyajian laporan keuangan itu sendiri (Prastowo, 2005 : 5). Laporan keuangan menggambarkan kondisi keuangan dan hasil usaha suatu perusahaan pada saat tertentu atau jangka waktu tertentu (Harahap, 2010 : 5).

Dalam Standar Akuntansi Keuangan disebutkan bahwa laporan keuangan merupakan bagian dari proses pelaporan keuangan. Laporan keuangan yang lengkap meliputi laporan keuangan atas 
kegiatan komersial dan atau sosial. Laporan keuangan kegiatan komersial meliputi laporan posisi keuangan, laporan laba rugi, laporan perubahan posisi keuangan (yang dapat disajikan dalam berbagai cara seperti laporan arus kas, atau laporan perubahan ekuitas), catatan dan laporan lain serta materi penjelasan yang merupakan bagian integral dari laporan keuangan (IAI, 2009 : 1-2).

\section{Prediksi Kebangkrutan}

Menurut Altman (1968), kebangkrutan adalah kesulitan likuiditas yang sangat parah sehingga perusahaan tidak mampu lagi menjalankan operasi. Namun perusahaan dapat dinyatakan benar-benar bangkrut apabila sudah ditetapkan secara hukum oleh pengadilan. Tujuan dilakukan prediksi kebangkrutan adalah untuk memperoleh peringatan awal mengenai kebangkrutan, karena informasi kebangkrutan sangat bermanfaat bagi beberapa pihak seperti (Hanafi dan Halim, 2007: 261) seperti:

1. Pemberi Pinjaman

Informasi kebangkrutan ini bermanfaat untuk mengambil keputusan tentang siapa yang akan diberi kredit, dan kemudian bermanfaat untuk kebijakan memonitor pinjaman yang ada. Selain itu kreditur juga dapat mengambil keputusan apakah akan segera menarik piutangnya atau menambah piutang untuk menyelamatkan perusahaan tersebut. Investor yang menganut strategi aktif akan mengembangkan model prediksi kebangkrutan untuk melihat tandatanda kebangkrutan seawal mungkin dan kemudian mengantisifikasi kemungkinan tersebut, sehingga investor dapat menentukan sikap terhadap sekuritas yang dimilikinya dan jika perlu mengadakan perjanjian baru dengan pihak manajemen.

2. Investor

Investor saham atau obligasi yang dikeluarkan oleh suatu perusahaan tentunya akan sangat berkepentingan melihat kemungkinan adanya bangkrut atau tidaknya perusahaan yang menjual surat berharga tersebut.

3. Pihak Pemerintah

Pada beberapa sektor usaha, lembaga pemerintah mempunyai tanggung jawab untuk mengawasi jalannya usaha perusahaan. Lembaga pemerintah mempunyai kepentingan untuk melihat tanda-tanda kebangkrutan lebih awal supaya tindakan-tindakan yang diperlukan dapat dilakukan lebih awal.

4. Akuntan

Akuntan mempunyai kepentingan terhadap informasi kelangsungan suatu usaha karena akuntan akan menilai kemampuan going concern suatu perusahaan.

5. Manajemen

Kebangkrutan berarti munculnya biaya-biaya yang berkaitan dengan kebangkrutan dan biaya ini cukup besar. Apabila manajemen dapat memprediksi kebangkrutan lebih awal, maka tindakan-tindakan penghematan dapat dilakukan, misalnya dengan melakukan merger dengan menawarkan perusahaannya kepada peminat agar terhindar dari kebangkrutan atau restrukrisasi keuangan. Pentingnya meramalkan kelangsungan usaha suatu perusahaan adalah karena faktanya tidak ada satupun pihak dalam perusahaan yang mengharapkan terjadinya kebangkrutan.

Kebangkrutan (Financial distress) merupakan suatu situasi dimana aliran kas operasi sebuah perusahaan tidak 
cukup memuaskan kewajiban-kewajiban yang sekarang (seperti perdagangan kredit atau pengeluaran bunga) dan perusahaan dipaksa untuk melakukan tindakan korektif. Financial distress mungkin membawa suatu perusahaan untuk menggagalkan suatu kontrak, dan itu mungkin melibatkan restrukturisasi finansial di antara perusahaan, para kreditornya, dan para investor ekuitasnya. Biasanya perusahaan dipaksa untuk mengambil tindakan yang ia tidak akan ambil bila ia memiliki aliran kas yang cukup (Sjahrial, 2007).

Financial distress merupakan sebagai suatu peringatan dini dari sebuah perusahaan untuk menghadapi masalah. Perusahaan dengan utang yang lebih besar akan mengalami financial distress lebih awal dari pada perusahaan yang memiliki utang yang kecil (Sjahrial, 2007).

Penilaian Z-Score merupakan salah satu alat untuk mengevaluasi kinerja keuangan perusahaan. Evaluasi kinerja keuangan perusahaan dapat dilihat dari berbagai sisi, salah satunya yakni dari sisi keuangan dengan memprediksi kondisi kesehatan keuangan perusahaan. Apakah perusahaan tersebut dalam keadaan sehat secara aspek keuangan atau tidak. Model prediksi kebangkrutan sudah dikembangkan ke beberapa Negara. Altman melakukan survei model-model yang dikembangkan di Amerika Serikat, Jepang, Jerman, Swiss, Brazil, Australia, Inggris, Irlandia, Kanada, Belanda, dan Perancis. Salah satu masalah yang bisa dibahas adalah apakah ada kesamaan rasio keuangan yang bisa dipakai untuk prediksi kebangkrutan untuk setiap Negara, ataukah mempunyai kekhususan (Hanafi dan Halim, 2007: 286287).

Menurut Altman, formulasi Z-Score yang digunakan adalah sebagai berikut:

$$
\begin{aligned}
& \mathrm{Z}=6.56 \mathrm{X} 1+3.26 \mathrm{X} 2+6.72 \mathrm{X} 3+1.05 \mathrm{X} 4 \text {. } \\
& \text { Dimana: } \\
& \text { X1 = Working Capital to Total Assets Rasio } \\
& \mathrm{X} 2=\text { Retained Earning to Total Assets Rasio } \\
& \text { X3 = Earning Before Interest and Taxes to Total } \\
& \text { Assets Rasio } \\
& \text { X4 = Market Value of Equity to Book Value of } \\
& \text { Total Liabilities } \\
& \mathrm{Z}=\text { Nilai } \mathrm{Z} \text {-Score }
\end{aligned}
$$

Bila dijabarkan satu persatu, maka formasi X1 sampai X4 adalah sebagai berikut:

1. Working Capital to Total Assets Rasio (X1)

$$
\mathrm{X} 1=\frac{\text { Working Capital }}{\text { Total Assets Rasio }}
$$

Rasio ini sering kali dijumpai dalam kajian permasalahan perusahaan, rasio ini merupakan pengukuran net liquit assets dari perusahaan terhadap kapitalisasi total asset. Modal kerja didefinisikan sebagai kelebihan aktiva lancar setelah dikurangi dengan hutang lancar. Biasanya sebuah perusahaan yang mengalami kerugian operasi berkelanjutan akan menyusut aktiva lancar (current assets) berkaitan dengan total aktiva.

2. Retained Earning to Total Assets Rasio (X2)

$$
\mathrm{X} 2=\frac{\text { RetainedEarning }}{\text { TotalAssetsRasio }}
$$

Rasio ini diukur dengan membandingkan antara laba ditahan dengan total asset perusahaan. Usia dari sebuah perusahaan implisit dipertimbangkan dalam rasio ini. Misalnya perusahaan yang relatif muda/baru mungkin menunjukkan rasio ini rendah karena perusahaan belum memiliki waktu untuk menyusun laba komulatifnya. 
3. Earning Before Interest and Taxes to Total Assets Rasio (X3)

$$
\mathrm{X} 3=\frac{\text { EBIT }}{\text { TotalAssetsRasio }}
$$

Rasio ini diukur dengan membandingkan antara pendapatan sebelum bunga dan pajak dengan total aktiva perusahaan. Pada dasarnya, rasio ini merupakan pengukuran dari produktifitas aktiva suatu perusahaan. Karena kriteria utama dari eksistensi perusahaan didasarkan pada daya pendapatan aktivanya. Rasio ini tampak secara khusus ditujukan untuk penelitianpenelitain yang berkaitan dengan kegagalan perusahan, selain itu, insolvensi dalam pengertian kebangkrutan terjadi ketika total kewajiban melebihi nilai aktiva perusahaan.

4. Market Value of Equity (MV Equity) to Book Value of Total Liabilities (X4)

$$
\mathrm{X} 4=\frac{\text { MVEquity }}{\text { BookValueofTotalLiabilities }}
$$

Market Value of Equity diukur dari hasil perkalian antara outstanding stock (jumlah saham yang beredar) dengan market price per share (harga pasar per lembar saham). Sementara jumlah hutang termasuk hutang lancar dan hutang jangka panjang. Pengukuran ini menunjukkan berapa banyak aktiva perusahaan dapat turun nilainya (diukur dengan nilai pasar dari ekuitas ditambah dengan hutang) sebelum kewajiban melebihi aktiva dan perusahaan menjadi insolvensi.

Kriteria penentuan apakah suatu perusahaan bangkrut atau tidak menurut Altman adalah :

1. Z-Score $\leq 1.10$, berarti kondisi kesehatan keuangan suatu perusahaan tidak baik dan diprediksi akan segera mengalami kebangkrutan.

2. $1.10>$ Z-Score < 2.60, berarti suatu perusahaan berada dalam gray area di mana suatu perusahaan berada dalam ambang kebangkrutan.

3. Z-Score $\geq 2.60$, artinya kondisi kesehatan keuangan suatu perusahaan berada dalam keadaan baik di mana perusahaan tersebut tidak diprediksi mengalami kebangkrutan.

Hasil penelitian yang dilakukan oleh Ayu Suci Ramadhani dan Niki Lukviarman (2009) dapat dilihat bahwa dengan menggunakan ketiga model Altman persentase perusahaan yang diprediksi bangkrut untuk perusahaan kecil memiliki persentase yang paling besar dari pada kebangkrutan untuk kelompok perusahaan besar. Ini menunjukkan bahwa perusahan kecil memiliki kemungkinan yang besar untuk mengalami kebangkrutan dari pada perusahaan besar.

Namun menurut hasil penelitian Marcelinda, dkk (2014) penggunaan model Altman untuk memprediksi kondisi kesehatan keuangan perusahaan di Indonesia perlu digunakan secara hatihati. Karena berdasarkan hasil penelitian yang dilakukan terhadap perusahaan manufaktur diperoleh hasil bahwa akurasi model Altman Z-Score relatif tidak sesuai dengan kondisi keuangan perusahaan sebagaimana yang diindikasikan oleh para auditor dalam memprediksi tingkat kebangkrutan atau kesehatan keuangan perusahaan di Indonesia.

\section{Hasil Penelitian}

Berdasarkan metode altman yang digunakan terhadap Lembaga Keuangan Mikro Syariah di Tanah Datar diperoleh hasil sebagai berikut: 
230 || Jurnal Ilmiah Sygari'ah, Volume lo, Nomor 2, Juli-Desenther 20016

Tabel 1.

Nilai $X 1, X 2, X 3, X 4$ dan Nilai $Z$

Lembaga Keuangan Mikro Syariah Tanah Datar tahun 2015

\begin{tabular}{|l|l|l|l|l|c|}
\hline \multicolumn{1}{|c|}{ Nama } & \multicolumn{1}{c|}{ X1 } & \multicolumn{1}{|c|}{ X2 } & \multicolumn{1}{c|}{ X3 } & \multicolumn{1}{c|}{ X4 } & \multicolumn{1}{c|}{ Z } \\
\hline \hline KJKS BMT EL AMIN & 1,27 & 0 & $-0,36$ & 0,59 & 1,49 \\
\hline KJKS BMT ALMAKMUR & 0,49 & 0,07 & 0,28 & 0,10 & 0,94 \\
\hline KJKS BMT AL-HIKMAH & 1,66 & 0,02 & 0,74 & 0,06 & 2,48 \\
\hline KJKS BMT DARUSSALAM & 0,69 & 0,11 & 0,15 & 0,19 & 1,14 \\
\hline BMT MAHMUD YUNUS & 3,10 & 0,06 & 0,44 & 0,95 & 4,50 \\
\hline KJKS BMT AMPEK JURAI & 1,15 & 0,056 & 0,12 & 0,16 & 1,49 \\
\hline KPN SYARIAH AL-IKHLAS & 5,75 & 0,09 & 0,22 & 0,90 & 6,97 \\
\hline
\end{tabular}

Sumber: data diolah

Dari tabel di atas dapat dilihat nilai z score KJKS BMT El Amin bernilai 1,49, nilai ini berkisar antara 1,10< $Z^{\prime \prime}<2,60$, artinya perusahaan berada dalam wilayah abu-abu (gray area). Hal ini terjadi karena nilai $X 2=0$, ini disebabkan karena lembaga ini tidak mempunyai Laba Ditahan pada tahun 2015. Kondisi lain yang terjadi adalah nilai X3 $=-0,36$, hal ini disebabkan pada tahun 2015 ini perusahaan mengalami kerugian yang cukup besar. Nilai $X 4=0,59$, artinya perusahaan mempunyai masalah solvabilitas, karena perusahaan lebih banyak didanai dengan hutang dibandingkan dengan modal sendiri. Walaupun mengalami kerugian pada tahun 2015 dan mengalami kesulitan solvabilitas, nilai $\mathrm{X} 1=1,27$, yang artinya perusahaan mempunyai modal kerja yang positiv, sehingga modal kerja/total aktiva yang bernilai positif.

Nilai $z$ score KJKS BMT ALMAKMUR sebesar 0,94, nilai ini berkisar pada $Z^{\prime \prime}<1,10$, artinya perusahaan berada dalam wilayah bangkrut (distress zone/ Bankruptcy). Hal ini terjadi karena nilai $\mathrm{X} 1=0,49$, artinya modal kerja perusahaan lebih kecil dari total aset yang dimiliki. Nilai $\mathrm{X} 2=0,07$, artinya laba ditahan perusahaan jauh lebih kecil dibandingkan dengan total aset yang dimiliki perusahaan, sehingga kontribusi dalam pengembangan perusahaan menjadi kecil. Nilai $X 3=0,28$, di sini dapat dilihat bahwa pada perusahaan ini baru bisa melakukan pengelolaan aset dalam jumlah yang sedikit untuk menghasilkan laba. Nilai $X 4=0,099$, dilihat dari nilai $X 4$ ini dapat diartikan perusahaan mengalami masalah solvabilitas, karena hampir 90 persen aset perusahaan dibiayai dengan hutang.

Nilai $\mathrm{z}$ score KJKS BMT ALHIKMAH sebesar 2,49, nilai ini berkisar pada $Z^{\prime \prime}>2,60$, artinya perusahaan berada dalam zona aman (safe zone/ Non Bankruptcy). Hal ini terjadi karena nilai $\mathrm{X} 1=1,66$ artinya aktiva lancar mampu menutupi hutang lancar. Nilai $X 2=0,02$, artinya laba ditahan perusahaan jauh lebih kecil dibandingkan dengan total aset yang dimiliki perusahaan, sehingga kontribusi dalam pengembangan perusahaan menjadi kecil. Nilai $\mathrm{X} 3=0,74$, di sini dapat dilihat bahwa pada perusahaan bisa melakukan pengelolaan terhadap aset dalam jumlah yang memadai untuk menghasilkan laba. Nilai $X 4=0,06$, dilihat dari nilai $X 4$ ini dapat diartikan perusahaan mengalami masalah solvabilitas, karena hampir 94 persen aset perusahaan dibiayai dengan hutang. 
Nilai z score KJKS BMT DARUSSALAM sebesar 1,14, nilai ini berkisar antara 1,10 $<Z^{\prime \prime}<2,60$, artinya perusahaan berada dalam wilayah abu-abu (gray area). Hal ini terjadi karena nilai $X 1=0,69$, artinya modal kerja perusahaan lebih kecil dari total aset yang dimiliki. Nilai $X 2=0,11$, artinya laba ditahan perusahaan jauh lebih kecil dibandingkan dengan total aset yang dimiliki perusahaan, sehingga kontribusi dalam pengembangan perusahaan menjadi kecil. Nilai $X 3=0,15$, di sini dapat dilihat bahwa pada perusahaan ini baru bisa melakukan pengelolaan aset dalam jumlah yang sedikit untuk menghasilkan laba. Nilai $X 4=0,19$, dilihat dari nilai $X 4$ ini dapat diartikan perusahaan mengalami masalah solvabilitas, karena hampir 81 persen aset perusahaan dibiayai dengan hutang.

Nilai $\mathrm{z}$ score BMT MAHMUD YUNUS sebesar 4,51, nilai ini berkisar pada $Z^{\prime \prime}>$ 2,60, artinya perusahaan berada dalam zona aman (safe zone/ NonBankruptcy). Hal ini terjadi karena nilai $\mathrm{X} 1=3,06$ artinya aktiva lancar mampu menutupi hutang lancar. Nilai $X 2=0,06$, artinya laba ditahan perusahaan jauh lebih kecil dibandingkan dengan total aset yang dimiliki perusahaan, sehingga kontribusi dalam pengembangan perusahaan menjadi kecil. Nilai $X 3=0,44$, di sini dapat dilihat bahwa pada perusahaan bisa melakukan pengelolaan terhadap aset dalam jumlah yang memadai untuk menghasilkan laba. Nilai $X 4=0,95$, dilihat dari nilai $X 4$ ini dapat diartikan perusahaan tidak mengalami masalah solvabilitas, karena hanya kisaran 5 persen aset perusahaan dibiayai dengan hutang.

Nilai $\mathrm{z}$ score KJKS BMT AMPEK JURAI sebesar 1,49 , nilai ini berkisar pada $1,10<Z^{\prime \prime}<2,60$, artinya perusahaan berada dalam wilayah abu-abu (gray area).
Walaupun nilai $\mathrm{X} 1=1,14$, artinya aktiva lancar mampu menutupi hutang lancar. Tapi nilai $\mathrm{X} 2=0,06$, artinya laba ditahan perusahaan jauh lebih kecil dibandingkan dengan total aset yang dimiliki perusahaan, sehingga kontribusi dalam pengembangan perusahaan menjadi kecil. Nilai $\mathrm{X} 3=0,12$, di sini dapat dilihat bahwa pada perusahaan ini baru bisa melakukan pengelolaan aset dalam jumlah yang sedikit untuk menghasilkan laba. Nilai X4 $=0,16$, dilihat dari nilai $X 4$ ini dapat diartikan perusahaan mengalami masalah solvabilitas, karena hampir 84 persen aset perusahaan dibiayai dengan hutang.

Nilai z score KPN SYARIAH AL IKHLAS sebesar 6,97, nilai ini BERADA pada $Z^{\prime \prime}>2,60$, artinya perusahaan berada dalam zona aman (safe zone) NonBankruptcy). Hal ini terjadi karena nilai $X 1=5,75$ artinya aktiva lancar mampu menutupi hutang lancar. Nilai X2 $=0,09$, artinya laba ditahan perusahaan jauh lebih kecil dibandingkan dengan total aset yang dimiliki perusahaan, sehingga kontribusi dalam pengembangan perusahaan menjadi kecil. Nilai $\mathrm{X} 3=0,22$, di sini dapat dilihat bahwa pada perusahaan bisa melakukan pengelolaan terhadap aset dalam jumlah yang memadai untuk menghasilkan laba. Nilai $X 4=0,90$, dilihat dari nilai $X 4$ ini dapat diartikan perusahaan tidak mengalami masalah solvabilitas, karena hanya kisaran 10 persen aset perusahaan dibiayai dengan hutang.

\section{PENUTUP}

\section{Kesimpulan}

Dari tujuh lembaga keuangan mikro syariah yang ada dan sudah berbadan hukum di Tanah Datar terdapat dua 
lembaga keuangan mikro syariah yang berada pada posisi aman, empat lembaga keuangan mikro syariah berada pada area abu-abu (gray area), dan satu perusahaan yang berada pada zona yang berpotensi untuk bangkrut. Untuk perusahaan yang berada pada area abu-abu (gray area), dan pada zona yang berpotensi untuk bangkrut, perlu mendapat perhatian serius dalam hal manajemen dan pendanaan. Karena kalau tidak diperhatikan dengan serius akan mengancam keberlangsungan usaha keuangan mikro ini ke depan.

\section{Saran}

Lembaga Keuangan Mikro Syariah merupakan solusi bagi masyarakat kecil yang mengalami keterbatasan akses untuk memperoleh dana sebagai tambahan modal untuk pengembangan usaha dari lembaga perbankan. Untuk itu keberlangsungan usaha LKMS ini perlu mendapat perhatian bersama dari pihak manajemen dan pemerintah daerah. Khususnya pihak managemen untuk mengawasi dan mengatasi terjadinya kebangkrutan dapat dilakukan dengan cara melakukan analisis terhadap laporan keuangan secara berkala. Analisis laporan keuangan merupakan alat yang penting untuk memperoleh informasi yang berkaitan dengan posisi keuangan perusahaan serta hasil yang telah dicapai sehubungan dengan pemilihan strategi perusahaan yang telah diterapkan. Dengan melakukan analisis laporan keuangan perusahaan, maka dapat diketahui kondisi dan perkembangan finansial perusahaan. Selain itu, juga dapat diketahui kelemahan serta hasil yang dianggap cukup baik dan potensi kebangkrutan perusahaan tersebut.

\section{DAFTAR KEPUSTAKAAN}

Adnan, M. Akhyar dan Eha Kurniasih. 2000. Analisis Tingkat Kesehatan Perusahaan Untuk Memprediksi Potensi Kebangkrutan Dengan Pendekatan Altman. Jurnal Akuntansi dan Auditing Indonesia (Volume 4. No. 2) Jakarta: IAAI.

Ankarath Nandakumar, T.P Ghosh, et all. Memahami IFRS Standar Pelaporan Keuangan Internasional. Terjemahan oleh Priyo Darmawan. 2012. Jakarta: PT. Indeks.

Ayu Suci Ramadhani, dan Niki Lukviarman. Perbandingan Analisis Prediksi Kebangkrutan Menggunakan Model ALTMAN Pertama, ALTMAN Revisi, dan ALTMAN Modifikasi dengan Ukuran dan Umur Perusahaan sebagai Variabel Penjelas (Studi pada Perusahaan Manufaktur yang Terdaftar di Bursa Efek Indonesia), Jurnal Siasat Bisnis Vol. 13 No. 1, April 2009

Bruce Mackenzie, Allan Lombard, et all. IFRS for SMEs untuk Usaha Kecil Menengah atau Entitas Tanpa Akuntabilitas Publik. Terjemahan Priyo Darmawan. 2012. Jakarta: PT. Indeks.

Darmawan Sjahrial. 2007. Manajemen Keuangan Lanjutan. Jakarta: Mitra Wacana Media.

Departemen Koperasi. Pendapatan Domestik Bruto Indonesia yang dihasilkan dari kegiatan Usaha Mikro, Kecil dan Menengah. (http://www.Depkop.go. id, diakses 5 Februari 2015).

Dwi Martani, dkk. 2012. Akuntansi Keuangan Menengah Berbasis PSAK. Jakarta: Salemba Empat.

Dwi Murdaningsih. 11 Desember 2014. Lembaga Keuangan Mikro Menyusut, Republika. 
Dwi Prastowo D, dan Rifka Juliaty.2005. Analisis Laporan Keuangan. UPP: AMP YKPN.

Ikatan Akuntan Indonesia. 2009. Pernyataan Standar Akuntasi Keuangan. Jakarta: Salemba Empat

Iska, Syukri dan Rizal. 2005. Lembaga Keuangan Syariah. Batusangkar: STAIN Batusangkar Press.

James Van Horne dan John Wachowicz. 2005. Fundamentals of Financial Manajemen Prinsip-Prinsip Manajemen. Jakarta: Salemba Empat.

Jhon D. Martin. 1999. Dasar-Dasar Manajemen Keuangan. Jakarta: PT Raja Grafindo.

Jumingan. 2011. Analisis Laporan Keuangan. Jakarta: PT. Bumi Aksara.

Kasmir. 2010. Pengantar Manajemen Keuangan. Jakarta: Kencana Media Group.

M. Ismail Yusanto dan M. Karebet Widjaja Kusuma. 2002. Mengagas Bisnis Islam. Jakarta: Gema Insani Press.

Mamduh M. Hanafi, dan Abdul Halim. 2007. Analisis Laporan Keuangan. Yogyakarta: UPP STIM YKPM.

Michell Suharli. 2006. Akuntansi Untuk Bisnis Jasa dan Dagang. Yogyakarta: Graha Ilmu.

Muhammad. 2005. Manajemen Dana Syariah. Jakarta: Ekonisia.
Munawir. 2004. Analisis Laporan Keuangan. Yogyakarta: Liberty. . 2010. Pengantar Manajemen Keuangan. Jakarta: Kencana.

Rodoni, Ahmad dan Herni Ali, HT. 2010. Manajemen Keuangan Jakarta: Mitra Wacana Media.

Sekretariat Negara RI, Biro PerundangUndangan Bidang Perekonomian dan Industri. UU No. 20 tahun 2008 tentang Usaha Mikro Kecil dan Menengah.

Sofyan Syafri Harahap. 2002. Teori Akuntansi Laporan Keuangan. Jakarta: Bumi Aksara.

2011. Analisis kritis atas Laporan Keuangan. Jakarta: PT Raja Grafindo Persada. . 2011. Teori Akuntansi. Jakarta: PT. Raja Grafindo Persada.

Shelly Olivia Marcelinda, Hadi Paramu, dan Novi Puspitasari. 2014. Analisis Akurasi Prediksi Kebangkrutan Model Altman Z-Score pada Perusahaan Manufaktur yang Terdaftar di Bursa Efek Indonesia. e-Journal Ekonomi Bisnis dan Akuntansi, 2014, Volume 1 (I): 1-3.

Umar, Husein. 2003. Evaluasi Kinerja Perusahaan. Jakarta: PT. Gramedia Pustaka Utama. 